\title{
BEGINSELS EN NORME
}

DIE behandeling van hierdie belangrike sake doen ons onder drie hoofde:

God-gehoorsaam

Gode-waardig

Mens-waardig

Wat is 'n norm?

'n Norm is 'n maatstaf, 'n reël. Met so 'n maatstaf meet jy nie net alleen ' $n$ handeling of daad en bepaal of dit goed of sleg is nie, maar dis 'n reël waardeur jy gelei word om te weet hoe jy behoort op te tree in die toekoms. Norme is dus baie belangrike rigsnoere en die vraag is al dikwels en tereg gevra: Word hulle van buite aan jou opgelê of is dit reëls wat uit die mens se eie binneste voortkom? Dit klink na dood-eenvoudige vrae, maar daar is en daar word voortdurend nog oor gedebatteer. 'n Mens kan dit verstaan, want as die norme van buite af op jou opgelê word, is hulle dwangmaatreëls en jyself is altyd daaraan onderhorig. Jy het nie die reg of bevoegdheid om daarvan te verskil nie met die gevolg dat jy gebind is. As die norme deur jou bepaal word, het jy weer alle seggenskap, alleenseggenskap en die vraag is of daar nie net soveel norme as persone sal wees nie, elkeen met sy eie norme.

Is daar versoening tussen die twee rigtings?

\section{God-gehoorsaam}

Ons praat van beginsels wat die grondslag is van alles - ook van ons norme. Beginsels is daardie beginpunte wat onveranderlik en onveranderbaar net aanvaar moet word. 'n Mens dink hulle nie uit en hulle is ook nie resultate van ons navorsing of wetenskaplike arbeid nie. Hulle kan nie bewys of omvergewerp word nie, want hulle is al daar voor jou redenering en is dus ons vertrekpunte waarby jy heel eerste moet begin. Daarom moet jy hulle net aanvaar.

Beginsels het dus ewigheidskenmerke en moet van Goddelike oorsprong wees, want alleen God is die absolute begin en alleen God is ewig. God is nie ' $n$ beginsel nie, maar God is die begin van alles en het na ons gekom met sy openbaring.

Dit is daarom belangrik dat ons God reg moet ken en dat ons die God van die Skrifte as Enigste moet erken en bely. Daarom doen die Christendom ook sendingwerk om dié wat ander gode vereer of naas God stel, te roep tot inkeer, bekering en hartgrondige aanvaarding van die enigste God. Afkerige Godeverering moet ' $n$ ander beginselgrondslag aanvaar en noodsaaklikerwys tot ander norme kom. Godgehoorsaam is die eerste eis vir verklaring van norme en daarmee bely ons dat God van buite ons die grondslag gee van alle norme en dit is hulle eiendomlike wesenskenmerk.

- Verskyn in: Die Kerkblad, 15 Mei 1974, 21-23. 


\section{Gode-waardig}

As ek God bely en aan Jesus Christus behoort, moet ek vra: Wat eis Christus van my? Die antwoord is dat God Hom geopenbaar het in sy Woord en dat ek daardie openbaring moet aanvaar en my daaraan onderwerp. Gods Woord is geen wetenskaplike boek nie, maar wel 'n godsdienstige boek en bepaal my verhouding tot God. Dit bevat daardie beginpunte wat almal religieus bepaald is. Ons kan sê dit is die boek van beginsels, grondstene wat onveranderlik is en bly. Hierdie beginsels is werklik bepalend en funderend vir die norme in my lewe.

Vandaar dat die Christendom ook geroep is om 'n eie lewe te lei en daar is geen aanpassing moontlik by ander godsdienste nie, omdat hy leef uit die Woord. Tree hy die wêreld in, eis hy aanvaarding van die Bybel as enigste boek en roep ook in sy sendingopdrag dat gebreek moet word met ander boeke van openbaring soos wat ons kry by die Mohammedanisme of Hinduisme of ander natuurlike religies.

Dit is Gode-waardig.

Ons leef vanuit God en sy Woord.

Ons is leesbare briewe van Christus, soos ranke wat groei uit die wingerdstok Jesus Christus en wat nie anders kan as om vrugte van bekering te dra nie. Christus en my vertikale band met Hom bepaal my lewenspatroon en beheers my lewe op horisontale vlak.

Dit is Gode-waardig, Godverankerd.

\section{Menswaardig}

Soos wat gelowiges in Christus is en soos ranke uit die wingerdstok groei, so is die band van norme ook met die Skriftuurlike beginsels. Ons lewens word deur norme gerig, gelei en bepaal en dit volg dan dat die norme in hulle wese uit die Skrif groei.

Daar is in hoofsaak twee soorte norme en hulle vertak dan weer in die veelvuldige norme wat die verskillende lewensterreine beheers. Ons noem hulle grondnorme en afgeleide norme.

GRONDNORME is baie nou verwant aan die Skrifgegewens en neem die volle openbaringsinhoud in hulle op. Die Skrif gee tog ook norme wat ongewysig deur ons aanvaar moet word. Die tweede tafel van die wet gee bepaald beheersende norme vir ons samelewing, soos: Jy mag nie doodslaan nie, Jy mag nie steel nie. God spreek hier en onder alle omstandighede, of dit oorlog of vrede is, of daar nood of honger is, geld Gods gebod en hulle mag nie by omstandighede aangepas word nie. Grondnorme is só belangrik, omdat net by oortreding van hulle is ons sondaars, skuldig voor God. Net soos by beginsels eis hulle onderworpenheid.

AFGELEIDE NORME is kragtens hulle aard uit grondnorme afgelei en mag nooit van hulle oorsprong losgekoppel word nie. Ook hierdie norme is dus nie willekeurig nie en verskil nooit van mens tot mens nie. Al wat hier gebeur is dat die grondnorme nader bepaal en verbreed word, gedifferensieer word tot sy volle 


\section{In die Skriflig}

omvang. So sê die grondnorm: Jy mag nie steel nie. Die afgeleide norme vind ons duidelik in die Heidelbergse Kategismus se verklaring waar genoem word as voorbeclde: bose dade en listige planne waarmee ons dink om die goed van ons naaste onsself toe te eien, met geweld of skyn van reg, soos met valse gewig, el, maat, ware, munt, woeker, gierigheid, alle misbruik en verkwisting van gawes. Ons is aan hierdie norme gehoorsaam en by oortreding is ons oortreders of misdadigers. By implikasie is ons natuurlik ook sondaars.

So word ons liefde teenoor ons naaste in die praktyk gebring en ons noem dit menswaardig. Elkeen is 'n koningsmens met 'n Koningswoord en koninklike beheersing van sy lewe. Met die kompas van Gods Woord staan ons midde in die volle lewe en ons norme is van onbesproke oorsprong.

So leef ons God-gehoorsaam, Gode-waardig en mens-waardig. selfwaardig en naastewaardig.

Ons is nou nog verskuldig om die antwoord te gee op die vraag: Is die norme dan net van buite deur God en sy Woord ons opgelê en hoe bepaal die afgeleide norme ons veranderende wêreld? 'n Volgende keer prat ons weer oor die Heilige Gees en sy vertroostende nabyheid in ons lewens. 